\title{
Senior high school students' understanding of Newton's laws in outer space: Identification of misconceptions
}

\author{
Winarti $^{1 *}$, Eko Pardiyanto ${ }^{2}$, Fajar Kurnianto ${ }^{3}$ \\ ${ }^{1,2}$ Physics Education Department, Universitas Islam Negeri Sunan Kalijaga, Yogyakarta, Indonesia \\ ${ }^{3}$ Postgraduate, Physics Education, Yogyakarta State University, Yogyakarta, Indonesia \\ *Corresponding Address: winarti@uin-suka.ac.id
}

\begin{tabular}{|c|c|}
\hline Article Info & ABSTRACT \\
\hline Article history: & $\begin{array}{l}\text { One of the most frequently observed explanations in misconceptions is } \\
\text { concentulal understanding. This research aimed to determine the senior hioh }\end{array}$ \\
\hline Received: June 04, 2021 & school students' conceptual understanding of Newton's laws in outer space. \\
\hline Accepted: October 05, 2021 & hers assumed that the research results would be rich in variation \\
\hline Published: October 30, 2021 & $\begin{array}{l}\text { by elaborating the item questions based on the precise step of Digital Story } \\
\text { Conceptual Change-Oriented as a learning medium. The researchers }\end{array}$ \\
\hline Keywords: & The applied instruments were fifteen two-tier \\
\hline $\begin{array}{l}\text { Conceptual hierarchy; } \\
\text { Digital story conceptual; } \\
\text { Change-oriented; } \\
\text { Newton's law in outer space; } \\
\text { Misconceptions. }\end{array}$ & $\begin{array}{l}\text { multiple-choice items. The researchers also used a non-test instrument, } \\
\text { namely an interview sheet. The researchers found related misconceptions in } \\
\text { Newton's law in outer space during the research. It was found that } 30 \% \text { of } \\
\text { students experienced misconceptions. The results are important for the } \\
\text { learning process that through identification, teachers could use strategy to } \\
\text { explain the materials. }\end{array}$ \\
\hline
\end{tabular}

(c) 2021 Physics Education Department, UIN Raden Intan Lampung, Indonesia.

\section{INTRODUCTION}

Physics has many abstract concepts and principles (Blatt, 1986; Serway \& Jewett, 1998) that are hard for students to interpret. However, they must understand physics excellently without any ambiguity (Sukma et al., 2019). The student's ability to identify and interpret physics concepts is an important prerequisite for using concepts to make more complex inferences or solve physics problems (Astalini et al., 2018; Suriawati \& Mundilarto, 2019; Mustari et al., 2020). The need for physics learning focused on critical thinking concerning new things based on the knowledge has been believed to be true (Milenković et al., 2016). Physics learning helps students develop themselves into individuals who have a scientific attitude, process the phenomenon and knowledge gained, and understand the phenomena around them work (Akmam et al., 2018; Kesuma et al., 2020).

The students' difficulty in understanding some of the basic concepts of physics has become the concern of teachers and educational practitioners (Muna, 2016; Winarti \& Budiarti, 2020a). Symptoms of misconception or better known as "misconceptions" often interfere with the learning process, especially for students in the process of accommodation knowledge (Suparno, 2013; Kurniawan, 2018). Misconception is an interpretation of the concepts in an unacceptable statement (Novak \& Gowin, 1984). Misconception is an irrelevant explanation or idea based on experts' scientific convention. Misconceptions can be an inaccurate understanding of a concept, conceptual mastery, classification of examples of concept application, concept interpretations, 
confusion of different concepts, and incorrect hierarchical relationships of concepts. Based on the causes, a misconception occurs due to students, teachers, textbooks, context, and teaching methods (Suparno, 2013; Kuczmann, 2017).

The misconception may arise from the students' preconceptions, associative thinking, humanistic thinking, wrong reasoning, wrong intuition, cognitive development stages, student abilities, and interest in learning (Erman, 2017; Jauhariyah et al., 2018; Janzing, 2019). The misconception comes from the teacher who does not master the material or incorrect understanding of the material. Incorrect explanations in the textbook or difficult-tounderstand wording may cause misconceptions in students (Trisniarti et al., 2020). Experiences and teaching methods that do not provide opportunities for students to convey their ideas also cause misconceptions.

Identification of students' misconceptions can be seen through the differences in student beliefs about the answers between students who do not understand and students who face misconceptions (Prihatni et al., 2016; Irwansyah et al., 2018; Supeno et al., 2018). Based on the analysis of students' conceptual understanding, the misconceptions that students often experience are not only caused by their incorrect answers (Ekici, 2016; Niss, 2017; Astalini et al., 2018). If the students do not believe their answers, they are categorized as not understanding the concept (Akmam et al., 2018; Supeno et al., 2018; Kesuma et al., 2020). If the students believe in their answers, but their answers are incorrect, they are categorized as having misconceptions (Irwansyah et al., 2018).

Most observations on misconception focus on conceptual understanding. Volfson examined the concepts of a hetero-aged population regarding the circular motion phenomenon within a circus (Volfson et al., 2020). Another finding also found generic science and interpersonal skills caused the conceptual hierarchy in misconception. These new parameters could be the additional reasons for misconception instead of the natural effects (Trisniarti et al., 2020). Other scholars deduced that misconception deals with the structure of knowledge. Basic rules, such as complete information, knowledge of related ideas, trained cognition, and basic principle knowledge, could remove the students' misconceptions. They are also useful to prevent or eliminate misconceptions (Basu et al., 2017; Kuczmann, 2017). The regular measurement related to students' misconceptions needs to perform to maintain the solution map to overcome the problems in the conceptual physics hierarchy. The issues have been identified before (Chung-Parsons \& Bailey, 2019; Fourtassi et al., 2020).

Based on the literature reviews, the researchers found that research on misconceptions of Newton's law in outer space has not been researched from different perspectives. Therefore, the researchers intended to fulfill the gap (Muna, 2016; Sulistri \& Lisdawati, 2017; Kurniawan, 2018; Kurniawan \& Muliyani, 2019). Thus, the researchers investigated the misconceptions from different perspectives. Otherwise, the researchers also suggested that the naïve explanations in misconceptions found in this research can be eliminated to find different results. By elaborating the item questions based on the precise step of DSCC (Digital Story Conceptual Change-Oriented) as a learning medium, the researchers assumed that the research results would be rich in variation (Lin et al., 2016; Kurniawan et al., 2019). It will be an alternative to reduce misconceptions in the high category, which is more than $70 \%$, because the researchers could determine the students' misconceptions (Kurniawan et al., 2019). The pilot study conducted also found that academic institutions have not applied wide diagnostics tests to find out the incorrect concepts that lead to misconceptions in 
Newton's law in outer space (Istiyono et al., 2019; Winarti \& Budiarti, 2020)

Based on the research background and the pilot study, this research aimed to determine the senior high school students' conceptual understanding of Newton's law in outer space. By differentiating the steps to collect the issues, the researchers found related misconceptions in Newton's law in outer space concepts. This research is expected to present a new indicator related to students' misconceptions in physics.

\section{METHODS}

The research consisted of three stages: the preparation stage, the implementation stage, and the data processing stage. The steps are presented in Figure. 1.

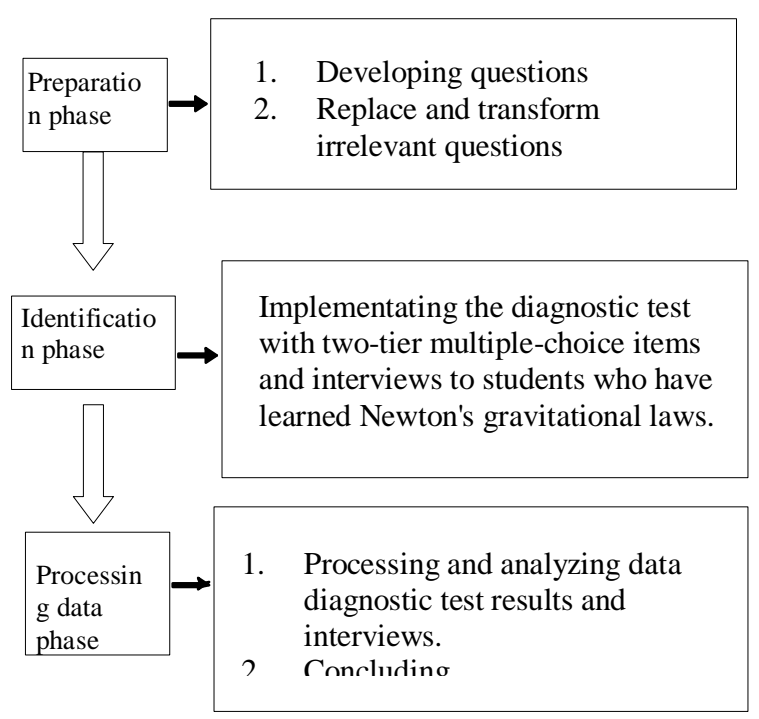

Figure 1. Research Flowchart

Descriptive research described the data based on the ongoing research process (Rukajat, 2018). The purpose of research using this method is to systematically describe the facts and characteristics of the research object accurately and without subjective assessment intervention. The researchers took all students in senior high schools in Yogyakarta as the population. The sampling technique was purposive sampling. The sample was taken as a representative of the population to facilitate the collection of research data. The sample consisted of six classes with 216 students as the participants. Based on the sampling process from three existing generations, the respondents of this study were students from six classes of the chosen educational institutions. The respondents gave their consent during the research.

The instrument of this research was chosen by the curatorial so that the test instrument was chosen. The applied instruments were fifteen two-tier multiplechoice items and a non-test instrument (interview sheet). The applied indicators were useful to (1) determine the influence of gravitational force, (2) analyze the lines of works and the direction of the interacted object gravitation, (3) identify the gravitational acceleration and field on different object positions, (4) analyze the correlation of the weight and the distances of objects, (5) analyze the correlation between gravitational acceleration and the height of the objects, and (6) analyze the planetary motion in the solar system based on Kepler's Law. The question item grouping was based on the misconception indicator and cognitive aspects. The first indicator had four items, the second indicator had two items, the third indicator had two items, the fourth indicator had two items, the fifth indicator had three items, and the sixth indicator had two items.

The test instrument was chosen to elaborate the students' answers and determine the misconceptions through the conceptual physics hierarchy. Thus, the comparison of each misconception's parameters can be determined and analyzed in context.

The logical validity from five experts showed that the test instruments were categorized high based on some considerations. They were (1) the grammatical matters for further revisions, (2) suggestions to make the questions to diagnose misconception, (3) the clarity of the figures and tables, and (4) the appropriateness of the core competence, objective indicators, and question indicators. 
The empirical validity results were compared with the critical values based on the product-moment table (0.316). The researchers found 23 valid questions, while four questions were invalid. The percentage of the valid questions was $85.185 \%$. The reliability test result of the questions was 0.926 . Thus, the question items were highly reliable.

The researchers analyzed and grouped the data into quantitative and qualitative data from the objective test and interview. Researchers used a test assessment scale to judge the objectiveness of the multiplechoice items.

Table 1. Test Assessment Scale

\begin{tabular}{|c|c|c|}
\hline No & The Students' Patterns & $\begin{array}{c}\text { Categories of } \\
\text { Understanding } \\
\text { Levels }\end{array}$ \\
\hline 1 & $\begin{array}{l}\text { Correct test answer - } \\
\text { correct reason }\end{array}$ & $\begin{array}{l}\text { Understand the } \\
\text { concept }\end{array}$ \\
\hline 2 & $\begin{array}{l}\text { Correct test answer - } \\
\text { incorrect reason }\end{array}$ & Misconception \\
\hline 3 & $\begin{array}{l}\text { Incorrect test answer - } \\
\text { correct reason }\end{array}$ & Misconception \\
\hline 4 & $\begin{array}{l}\text { Incorrect test answer - } \\
\text { incorrect reason }\end{array}$ & Misconception \\
\hline 5 & $\begin{array}{l}\text { Incorrect test answer - } \\
\text { incorrect reason }\end{array}$ & $\begin{array}{l}\text { Do not understand } \\
\text { the concept }\end{array}$ \\
\hline
\end{tabular}

From the tabulation of students' data based on the answer combination guideline, the researchers diagnosed and grouped the data into "understand the concept," "misconception," and "do not understand the concept."

The researcher used the following formula to calculate the percentage:

Remarks:

$$
P=\frac{\sum M}{\sum N} \times 100 \%
$$

$P \quad=$ Percentage

$\sum M=$ The numbers of students for each category

$\sum N=$ The total number of students

\section{RESULTS AND DISCUSSION Results}

The indicator identifications of the classes X MIPA 1 until X MIPA 6 are available in the following figure 2

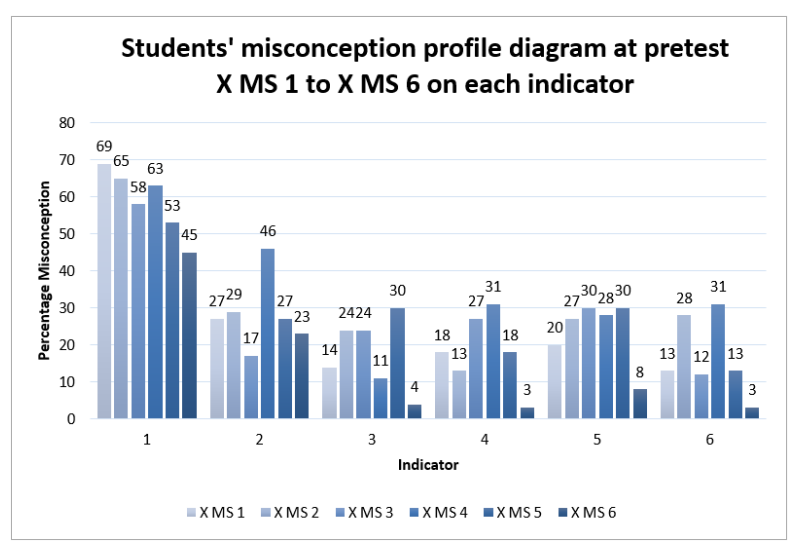

Figure 2. Students' Misconception Profile at Pretest on Each Indicator

Based on figure 2, classes X MIPA 1 until X MIPA 6 experienced misconceptions on each indicator with various values. The highest misconception percentage was on determining the gravitational force. In this indicator, the class X MIPA 1 obtained an average percentage of $69 \%, X$ MIPA 2 obtained 65\%, X MIPA 3 obtained 58\%, X MIPA 4 obtained 63\%, X MIPA 5 obtained $53 \%$, and X MIPA 6 obtained $45 \%$. On the other hand, the lowest percentage was on the indicator of analyzing planetary motion in the solar system based on Keppler's law. In this indicator, $\mathrm{X}$ MIPA 1 obtained a percentage of $13 \%$, X MIPA 2 obtained $28 \%$, X MIPA 3 obtained 12\%, X MIPA 4 obtained $31 \%$, X MIPA 5 obtained $13 \%$, and X MIPA 6 obtained 3\%.

The analysis results found 12 misconception categories for each indicator of Newton's law about gravity. They were (1) students assumed no spatial gravitational force, (2) students assumed the mass of the object influences object acceleration, (3) students assumed objects attract each other in horizontal positions, (5) students assumed the gravitational acceleration and gravitational force were equal, (6) students assumed the surficial distance of an object 
influenced gravitational force, (7) students assumed the size of an object influenced gravitational force, (8) students assumed moon would not fall, (9) students assumed gravitational force was equal for all falling objects, (10) students assumed the direction of gravitational force was influenced by object's motion, (11) students assumed the gravitational force of satellite was influenced by rotation time, and (12) students assumed the gravitational force of Earth is greater than the moon.

Based on the research results, many students experienced misconceptions. The students' conceptual hierarchy are determined in three stage of understanding which are "understand the concept", "do not understand the concept", and "misconception". The comparison of students' conceptual hierarchy related to Newton's law in outer space is shown in Figure 3.

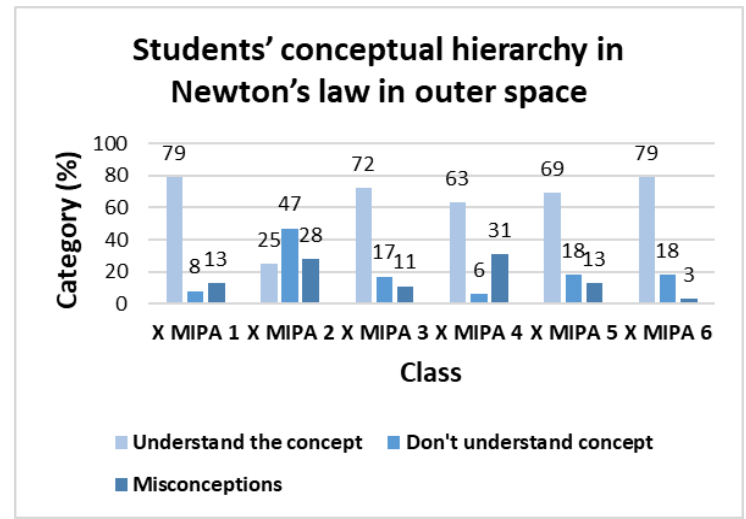

Figure 3. Students' Conceptual Hierarchy in Newton's Law in Outer Space

Figure 3 shows the students' understanding of Newton's gravitational law in space. The misconception occurred in all classes. The students assumed no gravitational force in space. Class X MIPA 2 had the highest misconception (28\%), and class X MIPA 6 had the lowest misconception (3\%).

The next finding is related to the relationship between gravitational acceleration (g) and the objects' height. It represents the concept of gravitational force
(F). The comparison of students' conceptual hierarchy related to this concept can be seen in Figure 4.

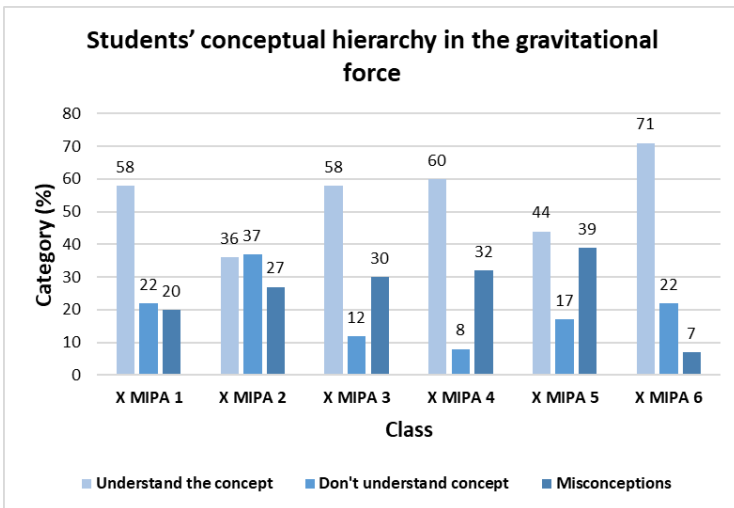

Figure 4. Students' Conceptual Hierarchy in the Gravitational Force

Figure 4 shows the students' understanding of the gravitational force. The researchers found misconceptions in all classes. The students assumed the gravitational force of all falling objects was the same. Class X MIPA 5 experienced the highest misconception (39\%). On the other hand, class $\mathrm{X}$ MIPA 6 experienced the lowest misconception (7\%).

The researchers found a misconception in analyzing the correlation between the acceleration and the height of an object. Students considered the object's mass influences the object's acceleration.

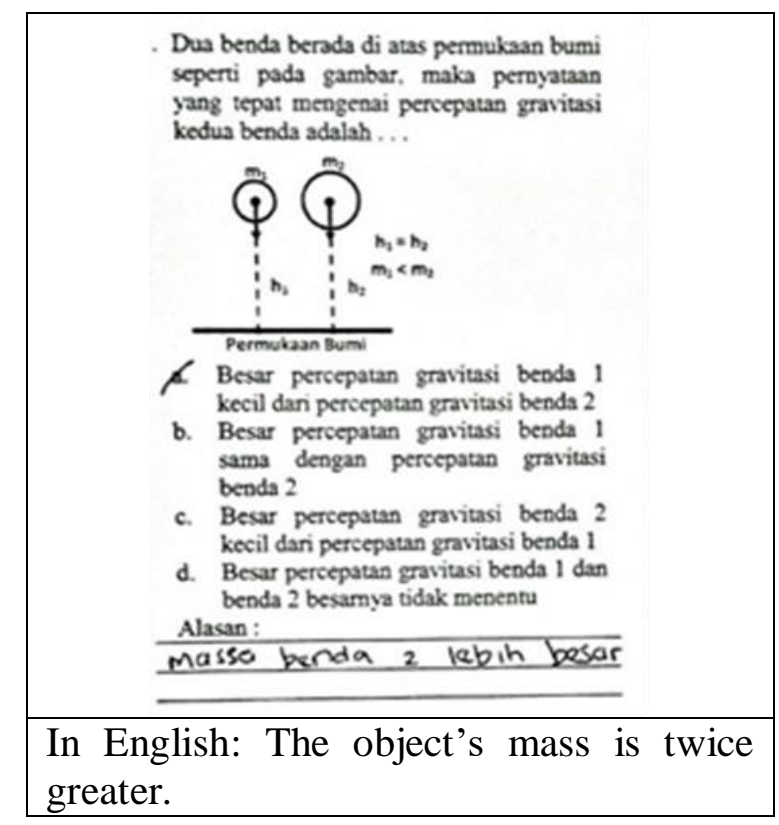


Two particles are above the ground (See the following figure). The correct statement about the particles is ...

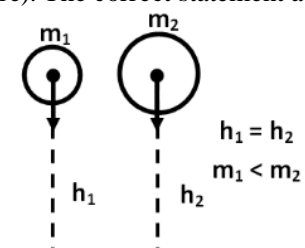

a. The magnitude of the gravitational acceleration

$\mathrm{X}$ of particle 1 is lower than the gravitational acceleration of particle 2 .

b. The magnitude of the gravitational acceleration of particle 1 is equal to the gravitational acceleration of particle 2 .

c. The gravitational acceleration of particle 2 is lower than the gravitational acceleration of particle 1 .

d. The gravitational accelerations of particles 1 and 2 are inconsistent.

Reason :

Mass of particle 2 is bigger

Figure 5. Item Sample on Two Objects with Different Height

Figure 5 illustrates two objects on the surface of the Earth with the same height (h), but the masses (m) of the two objects are different. The mass of object $1\left(\mathrm{~m}_{2}\right)$ is smaller than the mass of object $2\left(\mathrm{~m}_{1}\right)$. Based on this statement, the students were asked to determine the two objects' gravitational acceleration (g). The students answered that the gravitational acceleration of object 1 was smaller than object 2 because the mass of object 2 was greater than the mass of object 1 . Scientifically, the student's assumption was wrong (misconception) because the object's mass does not influence gravitational acceleration. Gravitational acceleration is affected by the object's distance to the center of the Earth, $m_{1}$ and $m_{2}$ have the same distance to the center of the Earth, so $\mathrm{ml}$ and $\mathrm{m}_{2}$ have the same gravitational acceleration. Students assume the acceleration due to gravity and the force of gravity is the same.

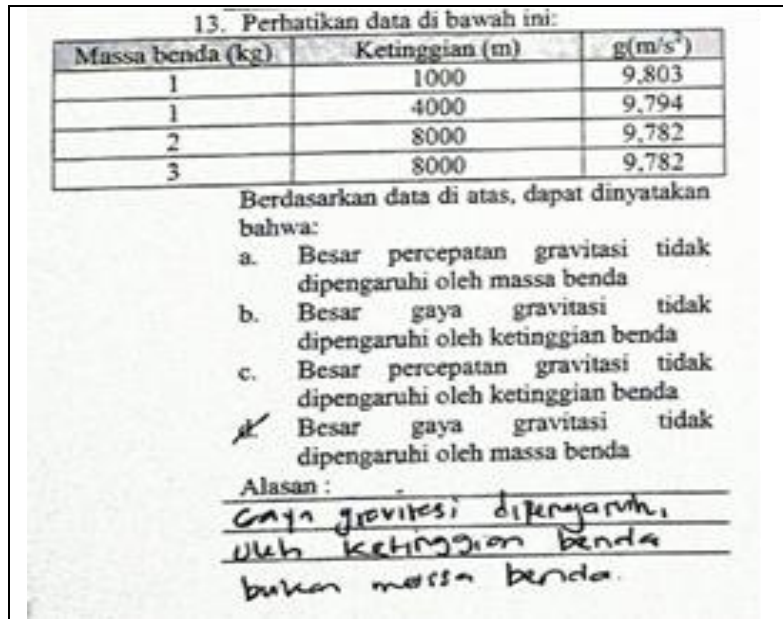

In English: The gravitational force is influenced by the object's height and the object's mass.

Attention to the data below :

\begin{tabular}{|c|c|c|}
\hline $\begin{array}{c}\text { Object's } \\
\text { Mass }(\mathrm{kg})\end{array}$ & Height $(\mathrm{m})$ & $\mathrm{g}\left(\mathrm{m} / \mathrm{s}^{2}\right)$ \\
\hline 1 & 1000 & 9,803 \\
\hline 1 & 4000 & 9,794 \\
\hline 2 & 8000 & 9,782 \\
\hline 3 & 8000 & 9,782 \\
\hline
\end{tabular}

From the data, it could be stated that ...

a. An object's mass does not influence the magnitude of gravitational acceleration.

b. The object's height does not influence $t$

c. he magnitude of gravitational force.

d. The object's height does not influence the

e. magnitude of gravitational acceleration.

f The object's mass does not influence

g. the magnitude of gravitational force.

Reason :

The Gravitational force is influenced by the object's height, not the object's mass.

Figure 6. Item Sample on the Relationship of Mass, Height, and Acceleration

Based on this problem, a table of the relationship between the mass of an object, height, and acceleration due to gravity was presented. The students were asked to choose the correct statement based on the data provided. The students' answers showed no influences between an object's mass $_{X}$ with the gravitational force. They thought that only the object's height influenced the gravitational force. Based on the answer, the student's assumption was wrong (misconception) because the gravitational acceleration is affected by the object's height. Therefore, there was a misconception of students who thought that 
gravitational acceleration and gravitational force were the same.

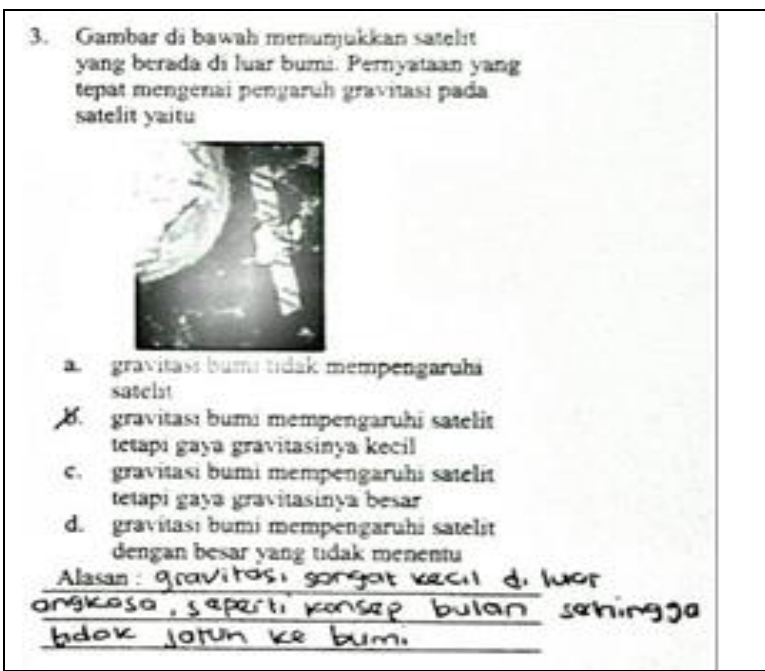

In English: In space, the gravitational force is lower, such as the moon. Thus, the moon will not fall.

The following figure shows an outer space satellite. The correct statement about the gravitational influence of the satellite is ...

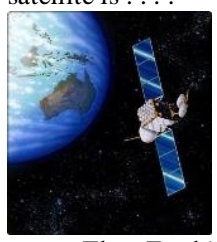

a. The Earth's gravitation does not influence the satellite.

\$. The Earth's gravitation influences the satellite, but it is minor.

c. The Earth's gravitation influences the satellite with high gravitational force.

d. The Earth's gravitation influences the satellite inconsistently.

Reason :

In outer space, the gravitational force is very small, like the concept of the moon, so it doesn't fall to Earth.

Figure 7. Item Sample on Planet Rotation and Revolution

The researchers found a misconception when the students analyzed the planetary motion inside the solar system and Keppler's Law. The students thought that the moon would never fall. Based on the problem above, a satellite image was presented. The students were asked to determine the correct statement about the gravitational force that influences the satellite. The students answered that the Earth's gravity affects the satellite, but its gravitational force is small because gravity is very small in space, like the concept of the moon so that it does not fall to the Earth. Based on these answers, the students answered correctly that the magnitude of the gravitational force in outer space is very small, but the student's assumption that the moon did not fall to Earth was wrong (misconception). The moon can fall to the Earth due to the force of gravity. Still, due to the effects of centripetal acceleration and centrifugal acceleration, the moon is always in its trajectory so that it does not fall to Earth. Students thought the rotation of a planet influenced the gravitational forces of the satellite.

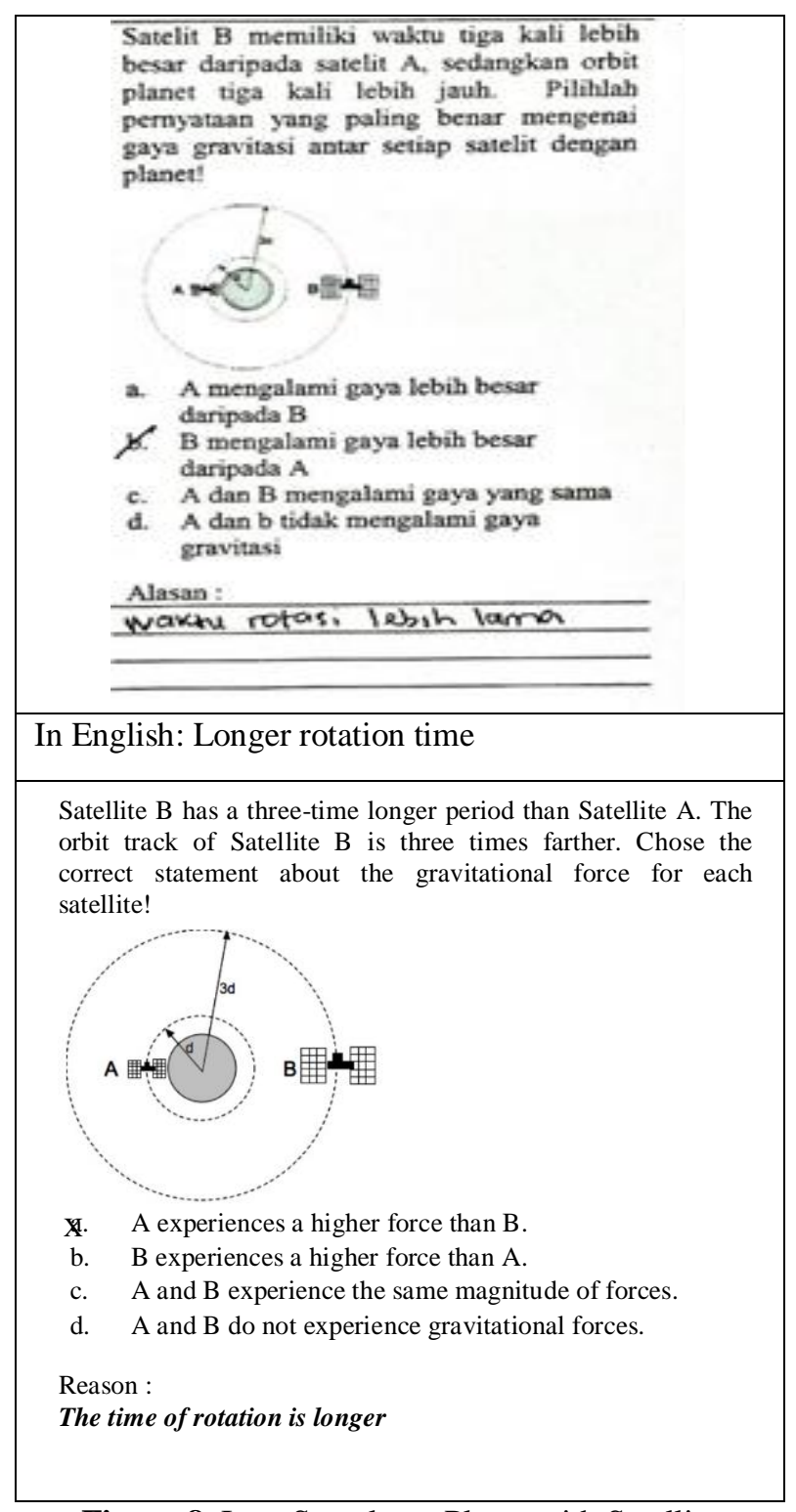

Figure 8. Item Sample on Planet with Satellite 
The problem above presented a picture of a planet surrounded by two satellites with different trajectories. Satellite B has a longer travel time than satellite A. The students chose the correct answers. They argued that Satellite B experiences a greater force than Satellite A because the rotation time is longer. The student's assumption was wrong (misconception) because objects with closer distances had greater gravitational force. This follows Keppler's III law that the smaller the distance, the greater the gravitational force, and vice versa.

\section{Discussion}

The findings were supported by the misconceptions in Newton's law in outer space (Comins, 2001; Temiz \& Yavuz, 2014; Rachmawati \& Susanto, 2017). Otherwise, the contra-contextual results that opposed the findings in this research were found through deeper analysis (Piburn, 1988; Supeno et al., 2018). A strong argument to support the finding was found in Supeno et al., (2018) and Aryani et al., (2019). The most salient relationship was between the sun and planets. The results indicated most had a reasonable concept of gravity. It was anticipated that the observed misconceptions could be corrected by an appropriately designed intervention (Piburn, 1988).

Nisa et al., (2019) found that the mastery of one-dimensional and two-dimensional motion concepts in SMA Negeri Bojonegoro was still low. On average, students could answer five out of twenty questions. The students experienced misconceptions about distance and displacement in a straight motion. It proves that the analytical thinking and critical thinking when learning science were still low and below average. Misconceptions found in the study also revealed that the students assumed that in a parabolic motion, the object's velocity is always perpendicular to its acceleration. Misconceptions about velocity vectors and acceleration vectors were caused by students' inability to distinguish vectors on the $\mathrm{x}$-axis and the $\mathrm{y}$ axis (Comins, 2001). Parabolic motion combines regular straight motion on the $\mathrm{x}$ axis and straight motion regularly changing on the y-axis (Serway \& Jewett, 1998). In a circular motion with constant speed, there were several difficulties experienced by students. They had difficulty in determining the velocity and acceleration vectors. It supported the finding related to the motion of the planet on gravitational force (Figure 6). The interviewed students stated that they thought the planet's gravitational force was not affected by the mass of the planets. They also thought that the planet's movement in rotation was not the same as circular or parabolic motion. The three-dimensional motion of the axis will lead to the same motion in Newton's law. Newton's law is applied in all kinds of motion through the projection of matter (Serway \& Jewett, 1998).

In line with the findings, previous research related to Newton's law in outer space also led to the same conclusion. Based on the students' reasons, they assumed that if the circular orbit radius was greater, the resulting gravitational force would also be greater. However, students who chose answer D gave unclear reasons, and some did not even give reasons.

This research only identified the students' initial misconception using a twotier diagnostic test and an interview. The test was for the class that learned Newton's Law concept about gravitation. This test was useful to obtain the initial data of the students' conceptual understanding. This research is interesting, and the researchers followed it up to remediate the misconception for future studies.

Many researchers discuss misconceptions and the relevant remediation as shown in this research. Some experts, including the current researchers, took some investigated concepts and relevant concepts based on our assumptions to be explored. The exploration of the conceptual hierarchy had also been done by Tatsar et al., (2020). The results 
revealed that students had conceptual changes positively after receiving the phenomenon-based authentic learning. They had the correct concepts in each isomorphic. Students' understanding of the concept as a whole after experiencing phenomenonbased authentic learning experienced positive changes. The results show an increase in student's conceptual understanding after being taught using phenomenon-based authentic learning. It cannot be separated from the learning process-oriented towards real phenomena to strengthen students' understanding of concepts (Hasanah et al., 2020). Some strategies and instruments are applicable to identify the misconception. The most important matter is how to improve the misconception, so the students' conceptual understandings are excellent and avoid further misconceptions in this learning material.

\section{CONCLUSION AND SUGGESTION}

The analysis found related misconceptions in Newton's law within the context of outer space. The researchers researched the senior high school students with various analysis approaches. The results showed that many students experienced misconceptions. The students' conceptual hierarchy was determined within three-stage, namely "understand the concept," "do not understand the concept," and "misconception." When the students analyzed the planetary motion in the solar system based on Keppler Law, the researcher found a misconception. The students thought that the moon would never fall apart.

This research is expected to present a new determination related to students' misconceptions in physics. The research on DSCC and related misconceptions in a different perspective, approach, and analysis needs to be conducted so that the findings in this study and previous related studies are not biased. The scope and sequence of research in the determination of misconceptions also need to be widened.

\section{REFERENCES}

Akmam, A., Anshari, R., Amir, H., Jalinus, N., \& Amran, A. (2018). Influence of learning strategy of cognitive conflict on student misconception in computational physics course. IOP Conference Series: Materials Science and Engineering, 335(1), 1-7. https://doi.org/10.1088/1757899X/335/1/012074

Aryani, W. D., Suhendi, E., Suyana, I., Samsudin, A., \& Kaniawati, I. (2019). Effectiveness of implementation interactive conceptual instruction (ICI) with computer simulation to overcome students' misconceptions about newton's law of gravitation. Journal of Physics: Conference Series, 1280(5). https://doi.org/10.1088/17426596/1280/5/052011

Astalini, A., Kurniawan, D. A., Perdana, R., \& Kurniasari, D. (2018). Identification of student attitudes toward physics learning at Batanghari district high school. The Educational Review, 2(9), 475-484. https://doi.org/10.26855/er.2018.09.00 3

Basu, S., Biswas, G., \& Kinnebrew, J. S. (2017). Student modeling for adaptive scaffolding in a computational thinking-based science learning environment. User Modeling and UserAdapted Interaction, 27(1), 5-53. https://doi.org/10.1007/s11257-0179187-0

Blatt, F. J. (1986). Principles of Physics. Allyn and Bacon.

Chung-Parsons, R., \& Bailey, J. M. (2019). The hierarchical (not fluid) nature of preservice secondary science teachers' perceptions of their science teacher identity. Teaching and Teacher Education, 78, 39-48. https://doi.org/10.1016/j.tate.2018.11.0 07 
Comins, N. F. (2001). Heavenly Errors: Misconceptions About the Real Nature of the Universe. Columbia University Press.

Ekici, E. (2016). "Why do I slog through the physics?": Understanding high school students' difficulties in physics learning. Journal of Education and Practice, 7(7), 95-107.

Erman, E. (2017). Factors contributing to students' misconceptions in learning covalent bonds. Journal of Research in Science Teaching, 54(4), 520-537. https://doi.org/10.1002/tea.21375

Fourtassi, A., Wilson, K., \& Frank, M. (2020). Discovering conceptual hierarchy through explicit and implicit cues in child-directed speech. Cognitive Science, 2430-2436. https://doi.org/10.31234/osf.io/s5q8u

Hasanah, N., Hidayat, A., \& Koeshandayanto, S. (2020). Pengaruh strategi konflik kognitif ditinjau dari kemampuan awal siswa untuk mengurangi miskonsepsi pada materi gelombang mekanik. Jurnal Pendidikan: Teori, Penelitian, Dan Pengembangan, 5(5), 624-629.

Irwansyah, I., Sukarmin, S., \& Harjana, H. (2018). Development of three-tier diagnostics instruments on students misconception test in fluid concept. Jurnal Ilmiah Pendidikan Fisika AlBiruni, $\quad 7(2), \quad$ 207-217. https://doi.org/10.24042/jipfalbiruni.v7 i 2.2703

Istiyono, E., Dwandaru, W. S. B., \& Muthmainah. (2019). Developing of bloomian HOTS physics test: Content and construct validation of the PhysTeBloHOTS. Journal of Physics: Conference Series, 1397(1), 1-9. https://doi.org/10.1088/17426596/1397/1/012017

Janzing, D. (2019). The cause-effect problem: Motivation, ideas, and popular misconceptions. In Cause Effect Pairs in Machine Learning. Springer.
Jauhariyah, M. N. R., Suprapto, N., Suliyanah, Admoko, S., Setyarsih, W., Harizah, Z., \& Zulfa, I. (2018). The students' misconceptions profile on chapter gas kinetic theory. Journal of Physics: Conference Series, 997(1), 1$13 . \quad$ https://doi.org/10.1088/17426596/997/1/012031

Kesuma, G. C., Diani, R., Hasanah, N., \& Fujiani, D. (2020). Blended learning model: Can it reduce students' misconception in physics? Journal of Physics: Conference Series, 1467(1), 1-11. https://doi.org/10.1088/17426596/1467/1/012044

Kuczmann, I. (2017). The structure of knowledge and students' misconceptions in physics. AIP Conference Proceedings, 1916, 1-6. https://doi.org/10.1063/1.5017454

Kurniawan, Y. (2018). Investigation of the misconception in newton II law. Jurnal Pena Sains, 5(1), 11-18. https://doi.org/10.21107/jps.v5i1.3879

Kurniawan, Y., \& Muliyani, R. (2019). A development design of digital story conceptual change-oriented in physics subject. Jurnal Ilmu Pendidikan Fisika, 4(2), 110-117. https://doi.org/10.26737/jipf.v4i2.1153

Kurniawan, Y., Muliyani, R., \& Nassim, S. (2019). Digital story conceptual change oriented (DSCC) to reduce students' misconceptions in physics. Jurnal Ilmiah Pendidikan Fisika Al-Biruni, 8(2), 211-220. https://doi.org/10.24042/jipfalbiruni.v0 i0.4596

Lin, J. W., Yen, M. H., Liang, J. C., Chiu, M. H., \& Guo, C. J. (2016). Examining the factors that influence students' science learning processes and their learning outcomes: 30 years of conceptual change research. Eurasia Journal of Mathematics, Science and Technology Education, 12(9), 26172646.

https://doi.org/10.12973/eurasia.2016.0 00600a 
Milenković, D. D., Hrin, T. N., Segedinac, M. D., \& Horvat, S. (2016). Development of a three-tier test as a valid diagnostic tool for identification of misconceptions related to carbohydrates. Journal of Chemical Education, 93(9), 1514-1520. https://doi.org/10.1021/acs.jchemed.6b 00261

Muna, I. A. (2016). Identifikasi miskonsepsi mahasiswa PGMI pada konsep hukum newton menggunakan certainty of response index (CRI). Cendekia: Journal of Education and Society, 13(2), 309-322. https://doi.org/10.21154/cendekia.v13i 2.251

Mustari, M., Anggereni, S., Sodikin, Fitria, \& Yusandika, A. D. (2020). Identification of students' misconceptions using the certainty of response index (CRI) from work and energy material. Journal of Physics: Conference Series, 1572(1), 1-10. https://doi.org/10.1088/17426596/1572/1/012038

Nisa, F., Yuliati, L., \& Mufti, N. (2019). Miskonsepsi konsep gerak satu dan dua dimensi siswa SMA. Jurnal Pendidikan: Teori, Penelitian, Dan Pengembangan, 4(10), 1380-1385.

Niss, M. (2017). Obstacles related to structuring for mathematization encountered by students when solving physics problems. International Journal of Science and Mathematics Education, 15(8), 1441-1462. https://doi.org/10.1007/s10763-0169754-6

Novak, J. D., \& Gowin, D. B. (1984). Learning How to Learn. Cambridge University Press.

Piburn, M. D. (1988). Misconceptions about gravity held by college students. In Annual Meeting of the National Association for Research in Science Teaching (Vol. 1, Issue 2).

Prihatni, Y., Kumaidi, K., \& Mundilarto, M. (2016). Pengembangan instrumen diagnostik kognitif pada mata pelajaran IPA di SMP. Jurnal Penelitian Dan Evaluasi Pendidikan, 20(1), 111-125. https://doi.org/10.21831/pep.v20i1.752 4

Rachmawati, S., \& Susanto, H. (2017). Penggunaan metode CRI (certainty of responseindex) berbantuan soal pisa (programme forinternational student assesment) untuk mengidentifikasi miskonsepsi IPA materi tata surya. Unnes Physics Education Journal, 6(3), 26-31. https://doi.org/10.15294/upej.v6i3.1931 0

Rukajat, A. (2018). Pendekatan Penelitian Kuantitatif: Quantitative Research Approach. Deepublish.

Serway, R. A., \& Jewett, J. W. (1998). Principles of Physics. Saunders College Publishing.

Sukma, T. A., Mundilarto, M., \& Putri, N. D. (2019). Local wisdom-based electronic book on newton's law. Jurnal Ilmiah Pendidikan Fisika AlBiruni, 8(2), 197-209. https://doi.org/10.24042/jipfalbiruni.v0 i0.4368

Sulistri, E., \& Lisdawati. (2017). Using three-tier test to identify the quantity of student that having misconception on newton's laws of motion concept. JIPF (Jurnal Ilmu Pendidikan Fisika), 2(1), 4-6.

https://doi.org/10.26737/jipf.v2i1.195

Suparno, P. (2013). Miskonsepsi dan Perubahan Konsep dalam Pendidikan Fisika. Grasindo.

Supeno, S., Subiki, S., \& Rohma, L. W. (2018). Students' ability in solving physics problems on newtons' law of motion. Jurnal Ilmiah Pendidikan Fisika Al-Biruni, 7(1), 59-70. https://doi.org/10.24042/jipfalbiruni.v7 i1.2247

Suriawati, S., \& Mundilarto, M. (2019). SETS approach-based audiovisual media for improving the students' critical thinking skills. Psychology, 
Evaluation, and Technology in Educational Research, 1(2), 95-103. https://doi.org/10.33292/petier.v1i2.15

Tatsar, M. Z., Yuliati, L., \& Wisodo, H. (2020). Eksplorasi pemahaman konsep siswa pada fluida statis berdasarkan authentic learning berbasis fenomena. Jurnal Pendidikan: Teori, Penelitian, Dan Pengembangan, 5(1), 107-113.

Temiz, B. K., \& Yavuz, A. (2014). Students' misconceptions about newton's second law in outer space. European Journal of Physics, 35(4), 1$16 . \quad$ https://doi.org/10.1088/01430807/35/4/045004

Trisniarti, M. D., Aminah, N. S., \& Sarwanto, S. (2020). Profile of senior high school students' misconception in physics using need-based analysis. Journal of Physics: Conference Series, 1567(3). https://doi.org/10.1088/17426596/1567/3/032072

Volfson, A., Eshach, H., \& Ben-Abu, Y. (2020). Identifying physics misconceptions at the circus: The case of circular motion. Physical Review Physics Education Research, 16(1), 111.

https://doi.org/10.1103/PHYSREVPH YSEDUCRES.16.010134

Winarti, W., \& Budiarti, I. S. (2020). Diagnostik konsepsi siswa ada materi suhu dan kalor. Jurnal Ilmu Pendidikan Indonesia, 8(3), 136-146. 